KaTARZYNA WALA

Uniwersytet Wrocławski

\title{
Ułożyć świat na nowo. Rekonstrukcja koncepcji Tima Ingolda (cz. II)
}

\section{Wprowadzenie}

$\mathrm{T}$

im Ingold ${ }^{1}$ jest $\mathrm{w}$ mojej ocenie jednym $\mathrm{z}$ najoryginalniejszych współczesnych antropologów wpisujących się w nurt myśli humanistycznej, wyrastający z krytyki kartezjańskiego modelu wiedzy. Jednym z zasadniczych celów tego nurtu jest zniesienie dualizmów charakteryzujących myśl zachodnią. Ingold tworzy spójny, autorski system myślenia, który ma na celu przekroczenie wskazanych ograniczeń filozoficznych i otworzenie antropologii na nowe byty i zjawiska - rzeczy, rośliny, zwierzęta, pogodę, architekturę. Jego teoria nie została jednak wyłożona w jednej publikacji, lecz - w pewnych fragmentach - jest obecna we wszystkich jego pracach. Niniejsza rekonstrukcja jest rezultatem skrupulatnej selekcji i łączenia poszczególnych wątków zawartych w jego licznych monografiach, artykułach, wywiadach i wykładach. W tym sensie jest ona autorską próbą interpretacji i prezentacji koncepcji Ingolda. Nie koncentruję się tutaj na ewolucji badań antropologa, stąd jego pisarstwo może wydać się statyczne, rozwijające się jedynie w zakresie tematyki badań, nie zaś samych koncepcji. Wydaje się, że

1 Tim Ingold (ur. 1948 r.) jest profesorem antropologii społecznej na University of Aberdeen oraz Royal Society of Edinburgh. Badania prowadził m.in. w Laponii, na Syberii i w północnej Europie. Zajmuje się także badaniami relacji i powiązań pomiędzy antropologią, architekturą, archeologią i sztuką. Jest autorem wielu publikacji, m.in.: The perception of the environment: essays on livelihood, dwelling and skill (2000), Being Alive: Essays on Movement, Knowledge and Description (2011), Making: Anthropology, Archaeology, Art and Architecture (2013), The Life of Lines (2015). 
rozwój poszczególnych koncepcji powinien być przedmiotem osobnego opracowania. Celem niniejszej pracy jest raczej próba spojrzenia na propozycję Ingolda jak na pewną całość. Osią tego przedsięwzięcia jest figura uzmysłowionego organizmu działającego w środowisku. Aby jednak ukazać sens, jaki zostaje jej nadany w pracach Ingolda, należy - zgodnie z jego dialektyczną metodą - zrewidować poglądy innych antropologów na temat środowiska, percepcji, organizmów i rzeczy.

Prezentowany tekst stanowi drugą część tryptyku publikowanego w czasopiśmie Etnografia. Praktyki, Teorie, Doświadczenia. W pierwszym artykule zostały omówione rozważania Ingolda na temat środowiska (dychotomia natura-kultura) oraz elementów, które tworzą jego tkankę, tj. pogody i rzeczy (dychotomia przedmiot-podmiot) (Wala 2016). W drugiej, niniejszej części, zostały opisane dociekania szkockiego antropologa na temat organizmów (dychotomia umysł-ciało) oraz percepcji i ruchu (dychotomia konstruktywizm kulturowy-realizm). Celem tej części jest połączenie wszystkich elementów teorii Ingolda - środowiska, rzeczy, organizmu i percepcji - i przedstawienie ich w świetle czterech zasadniczych tematów podejmowanych przez antropologa: produkcji, historii, zamieszkiwania i linii. W trzeciej części, planowanej na 2018 r., zostanie przedstawiona krytyczna analiza propozycji teoretycznej Ingolda, prezentowane założenia zostaną ukazane na tle rozwijanych w ramach współczesnej humanistyki i nauk społecznych płaskich ontologii i epistemologii relacyjnych (Jane Bennett, Rosi Braidotti, Donna Haraway, Bruno Latour itd.). Zostanie także omówiona postawa Ingolda wobec etnografii jako dyscypliny naukowej oraz przedstawiona ocena możliwości wykorzystania jego propozycji w praktyce badań terenowych.

Warto w tym miejscu zaznaczyć, że poszczególne części są opisywane zgodnie ze schematem, który uwidacznia się w wielu pracach Ingolda. Argumentacja $\mathrm{w}$ jego tekstach jest bowiem prowadzona według zasad swoistej dialektyki: zazwyczaj antropolog stara się zrekonstruować stanowisko swego oponenta, następnie osadzić je krytycznie w szerszej perspektywie myślenia, by w końcu przedstawić własne sądy i wykazać istotne różnice pomiędzy prezentowanymi koncepcjami. Inspirując się tym sposobem budowania i prezentowania myśli, interpretuję i prezentuję rozważania Ingolda poprzez zderzanie i ścieranie ich z pracami innych antropologów, socjologów i filozofów. W związku z tym konstrukcja niniejszego tekstu opiera się na następującym schemacie: 1) rekonstrukcja poglądów wybranych antropologów na temat cielesności i percepcji; 2) krytyka założeń, które leżą u ich podstaw; 3) prezentacja autorskiego programu Ingolda.

\section{Od ucieleśnienia do organizmu}

Stanowisko Ingolda na temat dychotomii umysłu i ciała jest formułowane nie tyle w odniesieniu do "bezcielesnej” antropologii konstruktywistycznej, co przede wszystkim wobec nurtu antropologii, który stawia w centrum ideę ucieleśnienia oraz odwołuje się do filozofii fenomenologicznej. 


\subsection{Ucieleśnienie}

W opublikowanym w 1983 r. artykule Knowledge of the body Michael Jackson przeciwstawia się dominującym $\mathrm{w}$ antropologii teoriom, $\mathrm{w}$ których ciało zostaje zredukowane do znaku, a praktyki cielesne są traktowane jedynie jako reprezentacja ukrytych znaczeń i struktur. Jego zdaniem tego rodzaju praktyk nie można zredukować do symboli - „choć są otwarte na interpretację, to same w sobie nie są interpretacją" (Jackson 1983: 339). Antropolog stara się zwrócić uwagę na cielesny i niedyskursywny wymiar uczestnictwa, powołując się przy tym na filozofię Maurice'a Merleau-Ponty'ego (2001: 76), który w Fenomenologii percepcji postuluje powrót do rzeczy samych, co oznacza „powrót do świata przeżywanego, mieszczącego się gdzieś poniżej świata obiektywnego, gdyż to w nim właśnie będziemy mogli zrozumieć zarówno prawa, jak i granice świata obiektywnego". Dla Jacksona (1983: 349) ów przedobiektywny sens doświadczenia jest równocześnie przedkulturowy: „Chciałbym podkreślić tu to, co wyrasta z samej ludzkiej egzystencji, zanim zostanie zrozumiane albo rozbudowane $\mathrm{w}$ terminach ściśle kulturowych".

W swojej pracy Jackson proponuje radykalny empiryzm, w myśl którego naśladowanie tubylczych czynności (practical mimesis) pozwoli antropologom uzyskać wgląd w sferę niewysłowionej, choć przyjętej powszechnie w obrębie danej zbiorowości wiedzy. W jego ocenie, „zamieszkując «ich świat», dostrajając własne ciała do czynności realizowanych przez badanych, nasze uczestnictwo staje się celem samym w sobie" (Jackson 1983: 340), a także metodą poznania antropologicznego, gdyż „rozpoznanie cielesności naszego bycia-w-świecie pozwala odkryć wspólny grunt (commonground), gdzie ja (self) i inny są jednym" (Jackson 1983: 340). U podstaw tego przekonania leży założenie, że to, co wygląda tak samo z racji posiadania takiej samej fizjologii, będzie znaczyło to samo i będzie tak samo doświadczane, niezależnie od różnic kulturowych i językowych, jakie dzielą uczestników działania. Ostatecznie oznacza to, że na poziomie doświadczenia cielesnego wszyscy ludzie są tacy sami.

Inaczej do tej kwestii podchodzi Thomas Csordas (1990: 5), dla którego „ciało nie jest przedmiotem, który można badać w odniesieniu do kultury, przeciwnie jest podmiotem tej kultury, jej egzystencjalnym gruntem". Żyjące i postrzegające ciało jest dla niego przesiąknięte kulturą i nawet na najbardziej egzystencjalnym i podstawowym poziomie nie można go zredukować do jego fizjologii (Csordas 1993: 136). Aby uniknąć nieporozumień wynikających z pisania o ciele, Csordas posługuje się pojęciem "u cieleśnienia" (embodiment), ponieważ odnosi się ono do czegoś więcej niż tylko do materialnego bytu i - jak wskazuje Honorata Jakubowska (2009: 276) - oznacza raczej pewne „pole badawcze zdefiniowane przez percepcyjne doświadczenie i sposób obecności oraz zaangażowania w świecie". Odwołując się do prac Merleau-Ponty'ego oraz Pierre'a Bordieau, Csordas dowodzi, że przedobiektywny poziom doświadczenia nie jest przedkulturowy, lecz "przedabstrakcyjny", "przedrefleksyjny". Stąd antropologia, przyjmując paradygmat ucieleśnienia, powinna stanowić opisową 
naukę egzystencjalnego początku, a nie tylko ukonstytuowanych obiektów kulturowych. Jej celem powinno być „uchwycenie tego momentu przekroczenia (transcendance), w którym percepcja się zaczyna i - pośród przypadkowości i nieokreśloności - ustanawia i jest ustanawiana przez kulturę" (Csordas 1990: 9). W ten sposób, zdaniem antropologa, paradygmat ucieleśnienia - z pomocą filozofii Merleau-Ponty'ego - pozwoli przełamać dualizm podmiotu i przedmiotu, natomiast dzięki rozważaniom Bourdieu - dualizm ciała i umysłu, znaku i znaczenia (Csordas 1990: 10-11). Kierunek tych rozważań wskazuje wyraźnie, że to, co dla Jacksona jest wyrazem jedności egzystencjalnej, według Csordasa jest raczej następstwem partycypowania we wspólnym habitusie, dzięki któremu ludzie mogą spontanicznie synchronizować swoje działania i współodczuwać stany drugiego.

Okazuje się jednak, że próbując uzupełnić antropologię o czującą i myślącą cielesność, napotykamy pewne ograniczenia. Csordas (1999: 145-146), w odróżnieniu od Jacksona, nie odrzuca tekstualizmu i semiotycznego podejścia do badań nad kulturą. Choć oba kierunki zakładają odmienne metody badań i analizy oraz prowadzą do różnych wniosków, to zdaniem antropologa badania somatyczne i semiotyczne mogą wzajemnie się uzupełniać ${ }^{2}$ Przedmiotem zainteresowań podejścia somatycznego jest szeroki zakres procesów i praktyk cielesnych, które z założenia są przedobiektywne, tzn. oddzielone od umysłu, języka i świadomej myśli, w podejściu semiotycznym badania mają charakter lingwistyczny, zaś ich przedmiotem są obiektywne reprezentacje. Ukazuje to pewien paradoks tego sposobu myślenia o cielesności - choć zarówno Csordas, jak i Jackson starają się tego uniknąć, ich propozycje są zakorzenione w tradycji kartezjańskiej (Farnell, Varela 2008: 224-225).

\footnotetext{
2 Pewne rozwiązanie tego problemu zostało zaproponowane przez Brendę Farnell i Charlesa Varela. W 2008 r. autorzy opublikowali artykuł The Second SomaticRevolution. Zaproponowana w nim perspektywa "dynamicznego ucieleśnienia" (dynamicembodiment) wyrasta z krytyki statycznego ciała (cielesności), doświadczenia oraz wąskiego pojmowania semiozy. W swoich pracach sugerują oni połączenie trzech perspektyw: mówienia o ciele, z ciała, ciałem (with the body, of the body, from the body). Podejście badawcze, które rozpatruje ciało jednocześnie $\mathrm{z}$ trzech różnych perspektyw, wymaga - zdaniem autorów - nowego spojrzenia na problem związków zachodzących pomiędzy analizą somatyczną i semiotyczną w badaniach społecznych. Propozycja Farnell i Vareli jest próbą połączenia tych podejść; warunkiem jej realizacji jest szerokie podejście do semiozy, której nie należy ograniczać jedynie do wytwarzania i przekazywania symboli i znaków. Badacze proponują podjęcie rozważań nad wielozmysłową semiozą, którą można określić jako proces sprawczego i cielesnego nadawania znaczeń za pośrednictwem (affordable) zmysłów smaku, słuchu, dotyku, bólu, zapachu, wzroku i kinestezji w różnorodnych związkach z mową i działaniami cielesnym. Innymi słowy, przyjmują oni, eż akt zmysłowy jest znaczący nie dlatego, że odnosi nas do czegoś, co znajduje się poza nim samym. Według autorów ma on znaczenie, ponieważ na jakimś poziomie jest rozumiany i zrozumiały, a to oznacza, że semioza - proces wytwarzania znaczenia - działa (Farnell, Varela 2008: 25; Farnell 1994, 1999).
} 


\subsection{Krytyka koncepcji ucieleśnienia}

Podobnie jak Jackson i Csordas, Ingold (2000: 170-171) podejmuje próbę włączenia do teorii antropologicznej rozważań Merleu-Ponty'ego i teorii praktyki Bourdieu, dostrzega jednak trzy zasadnicze przeszkody w rozwoju antropologii fenomenologicznej w kształcie zaproponowanym przez wspomnianych badaczy. Dwie $\mathrm{z}$ nich są zawarte $\mathrm{w}$ pracach podejmujących temat ucieleśnienia, trzecia zaś tkwi w założeniach przyjętych przez przedstawicieli nauk przyrodniczych. Wszystkie, zdaniem Ingolda, uniemożliwiają przekroczenie wskazanych wcześniej dychotomii umysłu i ciała.

Pierwszy problem, na który zwraca uwagę Ingold, wyrasta z niejasnego statusu nauk biologicznych w pracach Jacksona, Csordasa i wielu innych antropologów podejmujących temat cielesności i ucieleśnienia. Choć opowiadają się oni za przełamaniem dychotomii umysł-ciało, natura-kultura, to jednak rzadko podejmują kroki w kierunku złagodzenia podziału na naukę o życiu jako kategorii biologicznej i naukę o kulturze: „Integralność antropologii społecznej i kulturowej opierała się na przekonaniu o niezależności czy też autonomii kultury i biologii. Nawet teraz, gdy modne stało się mówienie o antropologii ciała - o ucieleśnieniu - antropolodzy bardzo niechętnie przyznają, że kulturowe procesy, które są ucieleśnione, są ipso facto biologiczne. Pragną pozostawać w pewnym oddzieleniu od biologii i mówić o ucieleśnionym «ja» (self), ucieleśnionej osobie, jako o istocie nie w pełni biologicznej. To właśnie ten podział kwestionuję" (Ingold 2000: 171).

W konsekwencji, stare podziały zostają utrzymane, a jedyne, co ulega zmianie, to pozycja ciała, które wcześniej było plasowane po stronie przyrodoznawstwa, obecnie zaś jest traktowane jako podmiot kultury (Ingold 2000: 170). Prowadzi to do drugiego problemu, który wynika z asymetrii, jaka zaistniała wraz z pojawieniem się nowego pojęcia - ucieleśnienia (embodiment). Wprowadzenie ciała do badań nad kulturą przyczyniło się do ekspozycji jednego elementu kosztem innych. Dobrym tego przykładem jest wezwanie Jakubowskiej (2012: 15) do rozwoju socjologii ciała, która uczyni samą cielesność swym zasadniczym przedmiotem: „Istnieje zatem potrzeba większej liczby badań, w których ciało/ ucieleśnienie interesowałoby nas jako przedmiot badań sam w sobie, a nie jako wskaźnik odnoszący do innych wymiarów życia społecznego".

Zdaniem Ingolda podobne postulaty dowodzą, że badacze ucieleśnienia nie zdołali przekroczyć kartezjańskich podziałów i kategoryzacji, a jedynie doprowadzili do ich wyrafinowanej reprodukcji.

Opisanych problemów nie można rozwiązać bez uprzedniego uporania się z trzecią i - jak twierdzi Ingold - najważniejszą przeszkodą, wytworzoną przez dominujące nurty nauk biologicznych, kognitywnych i psychologicznych. Chodzi mianowicie o pewną wizję organizmów, którą antropolog nazywa "ortodoksją bio-psycho-kulturową" (Ingold 2009: 113). Według niego wśród przedstawicieli biologii neodarwinowskiej, psychologii ewolucyjnej oraz klasycznej kognitywistyki istnieje zgoda co do pewnej zasady, według której „formy cielesne, zdolności intelektualne i dyspozycje behawioralne ludzi są określone niezależnie 
i z wyprzedzeniem wobec ich zaangażowania w konteksty praktycznej aktywności środowiskowej" (Ingold 2009: 117). Wszystkie są zapisane w genotypie i kulturze.

Ingold (2009: 117) rekonstruuje krytykowane przez siebie stanowisko, zgodnie z którym istoty ludzkie, podobnie jak istoty wszelkich innych gatunków, wykształciły się $\mathrm{w}$ procesie różnicowania poprzez dobór naturalny. Tym, co ewoluuje, nie jest jednak żywy organizm, lecz "formalna specyfikacja dotycząca organizmu, jego genotyp". Ewolucja genotypu odbywa się na przestrzeni wielu pokoleń, poprzez „,stopniowe zmiany spowodowane naturalną selekcją w częstotliwości jego elementów będących nośnikami informacji, czyli genów". Dlatego proces ontogenezy, a zatem wzrost i rozwój konkretnego organizmu, jest czymś osobnym wobec ewolucji gatunku: ,jego historia nie jest częścią tej ewolucji”. Tyczy się to także architektury umysłu. Przedstawiciele nauk kognitywnych przyjmują, że powstanie wewnętrznych struktur psychicznych, które umożliwiają poznanie, jest pochodną doboru naturalnego i genetyki.

W przypadku człowieka mamy jednak do czynienia z jeszcze jednym elementem wpływającym na jego rozwój. Zgodnie z popularnym poglądem przyjmuje się, że pod względem genotypu przedstawiciel późnego paleolitu niczym nie różni się od człowieka współczesnego. To, co ich różni, to proces historii, równoległy wobec ewolucji biologicznej rozwój kulturowy (Ingold 2004: 213). Oznacza to, że gatunek Homo sapiens „,wyewoluował, podobnie jak inne gatunki, w procesie naturalnej selekcji, dzięki której wyłoniły się pewne dyspozycje i zdolności, uniwersalne dla każdego przedstawiciela gatunku, niezależnie od kontekstu, w którym są one realizowane" (Ingold 2002: 7). Każdy z nas ma więc wrodzone, genetyczne wyposażenie, które odziedziczyliśmy po przodkach. Jednocześnie, $\mathrm{w}$ bezprecedensowym momencie historii naszej planety, ludzkość przełamała bariery natury, dzięki czemu rozpoczęła się historia człowieka wraz z jego zdolnością do tworzenia kultury - języka, symboli, sztuki, architektury, technologii (Ingold 2002: 7). Pod względem genetycznym ludzie różnią się od człowiekowatych i małp człekokształtnych raczej stopniem złożoności niż rodzajem. Pod względem zdolności do tworzenia kultury natomiast jest to już różnica nie stopnia rozwoju, lecz właśnie rodzaju (Ingold 2004: 213).

Stąd też, zdaniem antropologa, bierze się istota zachodniej myśli i nauki: rozwój ludzkości został wyjęty spod wpływu ewolucji natury, w której w dalszym ciągu uczestniczą pozostałe istoty żywe - zwierzęta, rośliny, bakterie, grzyby itd. O ile życie istot żywych jest zdeterminowane przez czynniki biologiczne, o tyle ludzie znaleźli sposób, aby od tej zależności się uwolnić. Nasza świadomość jest kształtowana w wyniku funkcjonowania istot ludzkich w intersubiektywnej domenie kultury i społeczeństwa, i jako taka pozwala nam kształtować i przekształcać naturę (Ingold 2002: 8). Ewolucja biologiczna jest procesem transformacji informacji genetycznej zakodowanej w DNA. Rozwój kulturowy jest natomiast mniej lub bardziej niezależny od transformacji genetycznej i odbywa się poprzez proces uczenia (Ingold 2004: 215). Kultura w tym ujęciu jest rozumiana jako 
„korpus wiedzy i informacji, wedle którego może ona być transmitowana między generacjami niezależnie od ich praktycznego zastosowania" (Ingold 2009: 116).

Biologia ewolucyjna, psychologia kognitywna i teoria kultury (pojmowane według Ingolda), widziane wspólnie, umożliwiają stworzenie syntezy istoty ludzkiej jako sumy trzech wzajemnie uzupełniających się elementów - ciała, umysłu i kultury. Działanie tego sposobu myślenia Ingold (2009: 112-113) wyjaśnia na przykładzie chodzenia i mówienia: „Aby dopełnić nasz obraz chodzącej, mówiącej istoty ludzkiej, musimy zatem połączyć trzy rzeczy: (a) ciało ludzkie z jego wbudowanymi strukturami anatomicznymi i zdolnościami poruszania się (kończyny do chodzenia, aparat głosowy do mówienia); (b) ludzki umysł z jego wpisaną na stałe (hardwired) architekturą obliczeniową mechanizmów przedstawiania; oraz (c) zespół specyficznie kulturowych reprezentacji lub programów, transmisję których między generacjami mechanizmy te umożliwiają".

Ingold twierdzi, że przedstawiony tu model jest błędny, ale nie ze względu na zawarty w nim, nieprzystający do prac współczesnych antropologów pogląd na kulturę, lecz z uwagi na umniejszenie w nim znaczenia ontogenezy. Przekroczenie ograniczeń dotychczasowej debaty na temat ucieleśnienia wymaga, zdaniem antropologa, nowego fundamentu w postaci komplementarnych twierdzeń z zakresu nauk biologicznych, psychologicznych i nauk o kulturze.

\subsection{Organizm-działający-w-środowisku}

Wskazując na ograniczenia prezentowanych koncepcji, antropolog decyduje się rozwijać własną perspektywę badawczą, opierając się na pracach przedstawicieli biologii rozwoju i psychologii ekologicznej oraz fenomenologii i teorii praktyki. Pomimo tego, że wskazane dziedziny wiedzy rozwijały się względnie niezależnie, zdaniem Ingolda, podzielają one pewne wspólne przekonania. Po pierwsze, sprzeciwiają się zakorzenionej w myśli zachodniej tendencji do przedkładania formy nad procesem, wskazując, że „życie nie jest odsłanianiem istniejącej już formy, lecz stanowi proces, w ramach którego jest ona generowana" (Ingold 2000: 173). Po drugie, tematem swoich badań i rozważań czynią one „organizm-w-jego-środowisku” (agent-in-its-environment) oraz fenomenologiczne „bycie w świecie”, nie zaś „,samoistny intelekt konfrontujący się z niezależnym od niego światem" (Ingold 2000: 173).

Innowacyjność propozycji Ingolda (2009: 120) w stosunku do opisanego wcześniej podejścia antropologów fenomenologicznych polega na zwróceniu uwagi na znaczenie ontogenezy (wzrost i rozwój konkretnego organizmu), ujawniającej się w tym, że „niemal każda zmiana rozwojowa organizmu ludzkiego jest natychmiast testowana w czasie i miejscu swego występowania”. Jak pisze Krzysztof Łastowski (2009: 11-12), komentując propozycję Ingolda: „W wyjaśnianiu prawidłowości nabywania przez organizm ludzki mentalnej i percepcyjnej sprawności poznawczej nie wystarczy odwołanie się do czynników dziedzicznych z jednej strony i środowiskowych (społecznych i kulturowych) z drugiej. Niezbędne tu jest 
jeszcze wskazanie na specyficzne prawidłowości wynikające z «epigenetycznego nadzoru» nad normalnym przebiegiem rozwoju w ontogenezie".

Epigenetyka to termin zaproponowany przez Conrada H. Waddingtona dla wyjaśnienia mechanizmów dziedziczenia pozagenowego (Dmitrzak-Węglarz, Hause 2009: 51). Jak wskazuje Łastowski (2009: 15-16), referując koncepcje Ingolda, „historia wydarzeń epigenetycznych, konkretny proces rozwoju osobnika ludzkiego, przebiegający w danym miejscu i czasie, ma znacznie większy wpływ na kształtowanie się umiejętności oraz kompetencji poznawczych człowieka niż inne czynniki, także je kształtujące. Zatem, obok wspólnych umiejętności typowych dla całego rodzaju ludzkiego w epigenezie pojmowanej procesualnie wykształcają się różnice przystosowawcze, jakie zawdzięczamy indywidualnym historiom życiowym".

Wynika z tego, że „formy i zdolności organizmu ludzkiego i innych można przypisać, w końcowym rozrachunku, nie tyle dziedziczności genetycznej, lecz generatywnym potencjałom systemu rozwojowego, a mianowicie całemu systemowi relacji tworzonych przez obecność organizmu, włącznie z jego genami, w określonym środowisku" (Ingold 2009: 120). Jak w innym miejscu pisze szkocki antropolog, ,jeśli geny wchodzą z czymś w interakcje, to są to inne elementy znajdujące się w komórce, które wchodzą w interakcje z innymi komórkami organizmu, które wchodzą w interakcje z innymi organizmami w świecie. To z tego wielopoziomowego procesu wyrastają (emerge) możliwości istot żywych. Innymi słowy, zdolności te są rezultatem działania całego systemu rozwojowego składającego się z organizmu, z jego szczególną genetyczną i komórkową budową, w środowisku. Stąd forma, jak i możliwości całego organizmu, włączając w to również istoty ludzkie, nie są w żaden sposób presprecyzowane, czy to kulturowo, czy też genetycznie, ale są własnościami systemu rozwojowego, które nieustannie wyłaniają się" (Ingold 2004: 217).

Ujmując rzecz prościej, Ingold odrzuca determinantę genetyczną i kultu rową. Dowodzi, że człowiek, podobnie jak inne istoty żywe, może rozwijać się w trakcie swojego życia, podejmując różnego typu działania w swoim otoczeniu: „Życie organiczne, jak zakładam, jest aktywne raczej niż reaktywne, twórczo rozwija się w całym polu relacji, w ramach którego organizm wyrasta, przyjmując szczególną formę, zawsze jednak w relacji do innych. Z tego punktu widzenia życie nie jest realizacją wcześniej ustanowionej formy, lecz jest samym procesem, w ramach którego forma jest generowana i realizowana" (Ingold 2000: 19).

Konsekwencją tego stwierdzenia jest konstatacja, zgodnie z którą „nie istnieje esencjonalna forma człowieczeństwa, nie ma sposobu, aby mówić, czym istota ludzka jest, poza różnorodnymi sposobami, dzięki którym ona powstaje (Ingold 1991: 359). Nie oznacza to jednak, że człowiek może być tym, kimkolwiek i czymkolwiek zechce zostać ${ }^{3}$. Mowa tu raczej o tym, że nie ma sposobu opisania tego,

\footnotetext{
${ }^{3}$ Jak w innym miejscu pisze Ingold (2009: 119-120): „Bez względu na warunki środowiskowe istnieją pewne rzeczy, które ludzie mogą potencjalnie zrobić, oraz takie, których zdecydowanie nie mogą. Niewątpliwie przekształcenie się człowieka w coś w rodzaju nietoperza wymagać
} 
czym jest istota ludzka, bez uwzględniania różnorodnych historycznych i środowiskowych okoliczności, w których kształtują się - wzrastają i prowadzą swoje życie - konkretni ludzie (Ingold 2004: 215). W tym sensie, jak pisze Łastowski, „Ingold stara się pokazać, że na rozwój ewolucyjny Homo sapiens należy obecnie spojrzeć poprzez przy pisanie znacznie większej istotności czynnikom historycznym towarzyszącym rozwojowi epigenetycznemu człowieka” (2009: 15).

Ingold (2009: 131) nazywa swoje podejście „myśleniem relacyjnym”, zaś Łastowski (2009: 15) przyporządkowuje tę propozycję do perspektywy poznawczej, która, jego zdaniem, coraz wyraźniej wyznacza nowy procesualny paradygmat w badaniach nad ewolucyjnym rozwojem ludzkich dyspozycji przystosowawczych. W jego ramach organizmy są traktowane nie jako odrębne, sprecyzowane jednostki, lecz jako „loci wzrastania i rozwoju w ramach nieprzerwanego pola relacji. Jest to pole, które urzeczywistnia się $\mathrm{w}$ aktywnościach życiowych organizmu i które jest urzeczywistniane (za sprawą procesów ucieleśnienia i umysłowienia) w swych specyficznych morfologiach, mocy ruchu oraz możliwościach świadomości i reakcji” (Ingold 2009: 131).

Mimo że badania nad związkami jednostki z jej otoczeniem były wielokrotnie podejmowane przez antropologów, to jednak Ingold (2000: 168) analizuje je nie tylko z perspektywy humanistycznej, lecz także w szerszym kontekście relacyjnym, w którym "stawanie się osoby (the comingintobeing of the person) jest częścią procesu stawiania się świata (process of coming-into-being of the world)". Dlatego też jego zdaniem takie procesy, jak myślenie, postrzeganie, zapamiętywanie i uczenie się muszą być osadzone w kontekście historii wzajemnych powiązań ludzi i ich środowiska: „Musimy przyznać, że umysł i jego własności nie są nam z góry dane wraz z wejściem jednostki do świata społecznego, są one raczej kształtowane $\mathrm{w}$ ramach życiowej historii zaangażowania w relacje z innymi. Wiemy, że dzieje się tak dzięki aktywności ucieleśnionego umysłu (lub umysłowionego ciała), poprzez który związki społeczne są formowane i przekształcane. (...) Badania nad tymi procesami, niezależnie od dyscypliny, w ramach której będą podejmowane, dotyczyć będą tego, jak organizmy postrzegają, działają, myślą, zdobywają wiedzę, uczą się i pamiętają w ramach wielostronnego, praktycznego zaangażowania w żywy świat" (Ingold 2000: 171).

będzie ogromnej zmiany genetycznej - wystarczająco ogromnej, by wykluczyć taką możliwość w odniesieniu do naszych potomków! Lecz choć różnica genetyczna może dostarczać pewnych wyjaśnień na temat tego, dlaczego ludzie nie umieją latać, a nietoperze nie potrafią chodzić, byłoby poważnym błędem wyciąganie stąd wniosku, że konkretna konstrukcja genetyczna nietoperza zawiera $\mathrm{w}$ sobie kod projektu skonstruowania mechanizmu lotu lub przeciwnie, że geny ludzkie kodują projekt zbudowania aparatu dwunożności. Źródło błędu tkwi w utożsamianiu różnic genetycznych z cechami formalnymi, triku, który, jak zauważył Paul Weiss, automatycznie przypisuje genom wyjątkową odpowiedzialność za organizację i porządek. Jedną rzeczą jest utrzymywać, że bez określonych modyfikacji genetycznych mających miejsce $\mathrm{w}$ genealogicznych liniach zstępujących prowadzących kolejno do nietoperzy i ludzi, nietoperze nie mogły latać, a ludzie nie mogli chodzić, lecz czymś zupełnie innym jest mówić o wskazaniu, w owych liniach zstępujących, «genów odpowiadających za latanie» czy «genów odpowiadających za chodzenie»". 
W konsekwencji Ingold (2009: 127) kładzie nacisk na historię rozwoju „całego organizmu-osoby, nierozdzielonego ciała i umysłu, aktywnie zaangażowanego w istotne komponenty środowiska". Dlatego też twierdzi, że błędem przedstawicieli różnych dyscyplin naukowych jest pisanie zarówno o samym, wyodrębnionym umyśle, jak i o samym, niezależnym ciele (ucieleśnieniu), ponieważ „W istocie rzeczy o «umysłowieniu» (enmindment) można by mówić podobnie jak o ucieleśnieniu (embodiment), gdyż rozwijanie pewnych wzorów ruchowych w świecie oznacza jednocześnie rozwijanie określonych modalności służących zajmowaniu się nim" (Ingold 2009: 127).

Warto zauważyć, że antropolog nie czyni wyraźnego rozróżnienia pomiędzy ludźmi i innymi żywymi organizmami. Według Ingolda (2002: 17) opis człowieka w kategoriach organizmu, jeśli przyjmiemy wskazane wcześniej założenia, nie jest redukcją, umysł jest raczej najbardziej zaawansowanym elementem procesu życia organizmu: „nie można odróżnić procesu, w którym istota ludzka zdobywa atrybuty osobowościowe w ciągu życia społecznego, od procesu ontogenetycznego rozwoju ludzkiego ciała w środowisku (...). Istota ludzka nie jest dwoma rzeczami: osobnikiem i osobą, ale po prostu organizmem”. Dostrzegając jednak różnice, jakie zachodzą pomiędzy ludźmi i innymi istotami żywymi, antropolog w wielu miejscach pisze o „organizmach-osobach"4.

Nawiązując do wcześniejszych fragmentów tego artykułu, należy wskazać, że Ingold nie zgadza się z poglądem Jacksona, według którego z samego tylko faktu posiadania ciał wszyscy doświadczamy w ten sam sposób. Odrzuca on także podejście Csordasa, według którego każde doświadczenie cielesne jest już w samej swej istocie kulturowe. Zdaniem Ingolda stanowiska te są błędne, ponieważ nie jest tak, że ludzie rodzą się biologicznie czy psychologicznie identyczni, potem zaś zostają zróżnicowani przez kulturę. Nie są oni także istotami kulturowymi z samego faktu urodzenia się w danym społeczeństwie. Jak stwierdza antropolog, „Wszystkie te specyficzne zdolności, które klasycznie przypisywano kulturze, w rzeczywistości zostają inkorporowane w przebiegu procesu rozwoju jako właściwości ludzkich organizmów. W tym sensie są one w pełni biologiczne. Kultura zatem nie jest ani nadorganiczna, ani też nadbiologiczna. Nie jest ona niczym dodanym do organizmów, lecz miarą różnic między nimi" (Ingold 2009: 130).

Antropolog wprowadza zatem zupełnie nowy i nieintuicyjny sposób myślenia o kulturze, pojmowanej jako miara różnic rozwojowych między organizmami. Pojęcie kultury nie ogranicza się zatem tylko do istot ludzkich, ale może obejmować także inne organizmy i komponenty środowiska.

\footnotetext{
${ }^{4}$ Antropolog przyznaje, że choć wszystkie organizmy żywe mają możliwość postrzegania, to tylko ludzie potrafią korzystać z wyobraźni: „zdolność ludzi do konstruowania wyobrażeniowych światów nie jest spotykana u innych gatunków, i to właśnie $\mathrm{z}$ tej zdolności wynika nasz język i kultura" (Ingold 2005: 85). Równocześnie jednak jest on konsekwentny w swym przekonaniu, że nadmierne podkreślanie znaczenia kultury(wąsko pojmowanej) i języka przysłania istotne podobieństwa pomiędzy wszystkimi organizmami żywymi, odnoszące się przede wszystkim do charakteru ich uczestnictwa w tworzeniu środowiska.
} 
Warto jeszcze raz podkreślić, że dotychczasowe rozważania odnoszą się do organizmów zanurzonych w środowisku, zaangażowanych w otaczający je świat. Owe zanurzenie i zaangażowanie wiążą się z pewnymi umiejętnościami, atencją, nastrojeniem percepcji i uwagi, sprzężeniem myślenia, postrzegania i działania. Zagadnienie organizmu działającego w środowisku narzuca zatem konieczność dalszego wyjaśnienia stosowanych przez antropologa kategorii.

\section{Zmysły i namysł. Edukacja uwagi}

W tej części artykułu zostaną omówione współczesne rozważania na temat percepcji, prowadzone w obrębie psychologii poznania, kognitywistyki, a szczególnie antropologii zmysłów, to bowiem wobec nich - a często w opozycji do niech - Ingold (2000: 243-287; 2011b; 2011c) buduje własną teorię, którą wyłożył przede wszystkim w książce The Perception of the Environment. Esseys of livelihood, dwelling and skills, szczególnie w rozdziale zatytułowanym Stop, Look and Listen!, a także w ramach debaty, która odbyła się na łamach czasopisma Social Anthropology/Anthropologie Sociale.

\subsection{Kanadyjska antropologia zmysłów}

Jeszcze do niedawna zmysły były traktowane jako temat nieistotny dla badań społecznych. Pomimo pewnych starań podjętych m.in. przez George Simmela (2006: 184-203), który na początku XX w. zainicjował powstanie socjologii zmysłów, musiało upłynąć jeszcze prawie pół wieku, zanim zmysły zostały dostrzeżone przez innych humanistów. Wprowadzenie zmysłów do antropologii odbyło się w dużej mierze za sprawą kanadyjskich badaczy pod wodzą Davida Howesa z Concordia University w Montrealu, którzy uznali, że percepcja ma podstawy w kulturze, a zatem, według Constance Classen (1997: 401), ,jest nie tylko aktem fizycznym, lecz również kulturowym. Wzrok, słuch, dotyk, smak i węch nie są wyłącznie środkiem ujmowania zjawisk fizycznych, lecz również kanałem transmisji wartości kulturowych". Kanadyjscy badacze zakwestionowali dominujące w myśli zachodniej przekonanie o transparentności zmysłów, wykazując równocześnie, że zakorzeniony w niej arystotelesowski porządek zmysłów, w którym uprzywilejowaną rolę odgrywa wzrok, jest w gruncie rzeczy konstrukcją kulturową. Ważnym wnioskiem z tych rozważań było stwierdzenie, że ka żda kultura może ujawniać inny wzór ludzkiego sensorium, a także odmienne hierarchie zmysłów. Poza tym, jak piszą Howes i Classen (1991: 259), jest również możliwe istnienie „różnorodnych porządków sensorycznych właściwych różnym grupom funkcjonującym wewnątrz społeczeństwa, np. kobietom i mężczyznom, dzieciom i dorosłym, przywódcom i robotnikom, przedstawicielom różnych profesji" (por. Howes 2005: 5). Co istotne, idiosynkratyczne aspekty doświadczenia nie stanowiły przedmiotu badań dla kanadyjskich 
antropologów. Uznawali oni bowiem, że kształt doświadczenia percepcyjnego jest zgodny ze wzorem dominującym w danym społeczeństwie i wyraża równowagę pomiędzy idiosynkratyczną specyfiką jednostki a narzucanymi społecznie normami (Howes 2003: 55). Michael Herzfeld (2004: 337) wyjaśnia to następująco: „dwie należące do tej samej kultury osoby mogą nie gustować w tych samych zapachach, jednak każda z nich będzie swe preferencje wyrażać w odniesieniu do zbioru z góry przyjętych kategorii". W dotarciu do kulturowych schematów sensorycznych miała pomóc analiza języka, kultury materialnej, mitologii, rytuałów i kosmologii (Howes, Classen 1999: 261). W tekstach kultury, praktykach i artefaktach bowiem są zawarte sensoryczne znaczenia i symbole. Jak pisze Howes (2003: 95), „smaki, dźwięki i dotyk są nasycone znaczeniami, starannie porządkowane i regulowane - wyrażają a jednocześnie ustanawiają porządek społeczny i kosmiczny".

Realizacja tych postulatów zaowocowała wieloma pracami poświęconymi m.in. poszczególnym modalnościom zmysłowym, historii kształtowania się zachodniego sensorium, zmysłowym porządkom wybranych kultur czy mediom. Wraz z rozwojem działalności kanadyjskich antropologów stopniowo wzrasta ich zainteresowanie praktykami społeczeństw nowoczesnych, pozawerbalną sferą doświadczenia, a także związkami, jakie zachodzą pomiędzy zmysłami (doświadczenie wielozmysłowe, synestezja), choć nie prowadzi to do całkowitego zerwania z badaniami nad wybranymi modalnościami zmysłowymi (Classen 2012). Nawet najważniejsi badacze z Concordia Sensoria Research Team w najnowszych pracach konsekwentnie odżegnują się od fenomenologii, która, ich zdaniem, prowadzi do uniwersalizacji doświadczeń sensualnych (Howes, Classen 2014: 9), niezmiennie też pozostają wierni założeniom umiarkowanego relatywizmu kulturowego. Jak zauważa Dorota Angutek (2010: 232-233), w y rażają oni tezę o niewspółmierności doświadczenia zmysłowego przedstawicieli rozmaitych kultur, a jednocześnie odcinają się od skrajnego relatywizmu epistemologicznego, który wyklucza możliwość poznania kulturowych światów Innego. Znamiennejednak dla tego podejścia pozostaje założenie, że ludzie wywodzący się z różnych kultur żyją w odmiennych światach zmysłowych. Właśnie m.in. to przekonanie kwestionuje Ingold.

\subsection{Krytyka antropologii zmysłów}

Zarzuty Ingolda wobec kanadyjskiej antropologii zmysłów odnoszą się do samych podstaw subdyscypliny, a dokładnie - do postulatu otwartości wobec tubylczych teorii percepcji oraz równoczesnego, arbitralnego stwierdzenia, że są one produktem kulturowym. Sytuując w centrum zainteresowań antropologii zmysłów bezcielesne „idee” i „wierzenia”, a także uznając doświadczenia sensoryczne za medium pozwalające wyrażać pozazmysłowe wartości (Ingold 2000: 156), kanadyjscy antropolodzy wpisują się w omówione już w pierwszej 
części artykułu (Wala 2016) podejście w antropologii, według którego jedyne, do czego mamy dostęp, to „reprezentacje natury, mniej lub bardziej zaburzone i uformowane przez ludzkie założenia kulturowe” (Ingold 2003: 84). Jak zauważa Ingold (2003: 84), „perspektywa ta zamyka ludzkość w jej własnym świecie - albo raczej w wielu światach odpowiadających poszczególnym kulturom, każdemu systemowi podzielanych i trwałych wyobrażeń symbolicznych. Poza nimi znajduje się zewnętrzna rzeczywistość, zwana zamiennie «naturą» lub «światem fizycznym». Rzeczywistość ta jest źródłem surowych danych istotnościowych, które same w sobie nie są uporządkowane ani nie mają znaczenia".

Choć celem Howesa i jego współpracowników miało być przełamanie zachodniej epistemologii, to jednak także oni wpadli w jej pułapkę, przyjmując założenia konstruktywizmu kulturowego. Trudno zatem, zdaniem Ingolda (2003: 84), wyobrazić sobie paradygmat bardziej kulturowy i w większym stopniu historyczny niż ten, który zakłada, że paradygmaty Innych (niezależnie od tego, czy tubylcze, czy naukowe) są w gruncie rzeczy wytworem kultury.

Na tym jednak nie kończą się wskazane przez Ingolda paradoksy kanadyjskiego projektu antropologii zmysłów. Jego zdaniem, założeniom Howesa towarzyszą niewyartykułowane przekonania na temat natury percepcji, zbieżne z założeniami kognitywizmu (komputacjonizm, koneksjonizm), który przez długi czas stanowił dominujący paradygmat w naukach o poznaniu (Ingold 2011b: 314). Jego podstawę stanowi przyjęcie prymatu wrażeń nad spostrzeżeniami. Oznacza to, że „nie mamy bezpośredniego dostępu do świata fizycznego, nasz mózg musi wnioskować na jego temat na podstawie topornych wrażeń, jakie otrzymuje od oczu, uszu i pozostałych narządów zmysłów" (Firth 2011: 71). Tym, co powstaje w naszym umyśle, jest reprezentacja rzeczy wistości, i to właśnie z nią i tylko z nią - mamy bezpośredni kontakt. Zgodnie $\mathrm{z}$ tą teorią do świadomości nie docierają bezpośrednio cechy przedmiotów zewnętrznych, obserwuje ona jedynie pewien stan powstały wewnątrz narządów zmysłowych, tzw. wrażenia zmysłowe, nie zaś sam przedmiot, np. dom czy drzewo.

Zestawienie poglądów kanadyjskich antropologów, zajmujących się tematyką zmysłów, z rozważaniami psychologów oraz przedstawicieli nauk kognitywnych pozwala zwrócić uwagę na pewne podobieństwa czy - jak pisze Ingold - swoistą komplementarność tych stanowisk, wynikającą z założeń a priori przyjętych przez badaczy. W opisanych przypadkach przyjmuje się bowiem, że świat „sam w sobie nie istnieje" (idealizm), a nawet jeśli istnieje, to jest on niedostępny ludzkiemu poznaniu, oraz że jedyne, do czego mamy dostęp, to reprezentacje tego świata (reprezentacjonizm), w pierwszym wypadku uformowane przez kulturę (konstruktywizm kulturowy), w drugim przez mózg (kognitywizm: komputacjonizm, koneksjonizm). Podsumowując, Ingold (2011c: 326) zarzuca kanadyjskim antropologom, że pomimo wielu deklaracji nie zrywają oni z zachodnią teorią poznania, zgodnie z którą „ludzie nadają sens rzeczom i światu poprzez nakładanie gotowych znaczeń na powierzchnię żywego doświadczenia, aby przy użyciu symboli ukształtować chaotyczny materiał surowych wrażeń”. Dlatego też sugeruje on gruntowne przeformułowanie subdyscypliny: „jeśli chcemy 
zrozumieć, jak powstają znaczenia, musimy zacząć od życia społecznego, nie zaś od kulturowych modeli danej kultury" (Ingold 2011c: 326). Według Ingolda podejście to pozwoli nam wyjaśnić różnice w sposobach postrzegania, które są właściwe dla przedstawicieli różnych społeczeństw. Warunkiem tego jest jednak przemyślenie na nowo samego zagadnienia percepcji.

\subsection{Edukacja uwagi}

Podchodząc do zagadnienia percepcji, Ingold szuka pomocy u badaczy zainspirowanych psychologią postaci i fenomenologią: Maurice'a Merleau-Ponty'ego, Jakoba von Uexkülla, a przede wszystkim Jamesa Gibsona. Szczególnie ważne są dla niego rozważania ostatniego badacza, dlatego, rekonstruując podejście Ingolda, będę odnosić się głównie do założeń autora The Ecological Approach to Visual Perception.

Gibson nie zgadza się z dominującym w psychologii poglądem, według którego organizm nie widzi przedmiotów i zjawisk w otaczającej go rzeczywistości, ale tworzy reprezentację zewnętrznego świata na podstawie odkodowanych impulsów elektrochemicznych, powstających w układzie nerwowym. Gibson (1979: 147) opowiada się za antyreprezentacjonizmem (prymat spostrzeżeń nad wrażeniami) i teorią bezpośredniego postrzegania: „Kiedy twierdzę, że percepcja środowiska jest bezpośrednia, to rozumiem przez to, że nie jest mediowana przez obrazy na siatkówce, obrazy neuronowe czy obrazy psychiczne. Percepcja bezpośrednia jest aktywnością brania informacji z otaczającego ułożenia światła (ambientopticarray)".

Tak rozumiana percepcja opiera się na funkcjonowaniu całego systemu, składającego się zarówno z organów, receptorów, jak i mózgu, razem z ich neuronowymi i mięśniowymi odgałęzieniami w środowisku, nie zaś na aktywności samego organu zmysłowego i mózgu. Jak pisze Gibson (1966: 1): „mówi się, że widzenie zależy od oka, które jest połączone z mózgiem. Sugeruję, że naturalne widzenie zależy od oczu umieszczonych na głowie złączonej z ciałem znajdującym się na ziemi. Mózg jest jedynie centralnym organem kompletnego systemu wzrokowego". Ingold (2005: 79) streszcza tę myśl, wskazując, że „to całość organizmu postrzega, a nie tylko umysł, a rezultatem nie jest spostrzeżenie, ale nowy stan spostrzegającego". Postrzeganie zaś jest równoznaczne z procesem działania. Poruszając się w środowisku, aktywnie poszukujemy i zapamiętujemy informacje określające niezmienne własności i cechy obiektów, które napotykamy. Gibson (1966: 1) pisze: „Zawsze zakłada się, że zmysły są kanałami wrażeń. Może wydawać się rzeczą dziwną rozpatrywać je (...) jako systemy percepcji. Jednakże jest faktem to, że istnieją dwa różne znaczenia czasownika doznawać (to sense). Pierwsze, wykrywać coś (to detect something), i drugie, mieć doznanie (to have sensation). Gdy zmysły są rozpatrywane jako systemy percepcyjne, używane jest pierwsze znaczenie". 
Tak pojmowany system percepcyjny sposobem swego funkcjonowania przypomina macki i czułki. Jak twierdzi Gibson (1966: 5), „systemy percepcyjne, włączając ośrodki nerwowe na różnych poziomach organizacji mózgu, są sposobami poszukiwania i wydobywania (seeking and extracting) informacji o środowisku z napływającego ustrukturyzowanego szyku strumienia (opticarray) otaczającej energii”. Gibson głosił tezę, że „struktury i znaczenia, które znajdujemy w świecie, tkwią już w informacji, którą wyciągamy w akcie postrzegania" (Kaliski 2008: 58-62). Źródło tych struktur i znaczeń leży w obiektach, które postrzegamy, nie są one dodawane przez postrzegającego. Stąd, jak pisze Ingold (2005: 79), „postrzeganie jest ipso facto dowiadywaniem się - zobaczyć coś, oznacza spostrzec informację, pozwalającą na dowiedzenie się". Percepcja jest więc rozumiana jako proces brania (picked-up) informacji ze środowiska, polega na wychwytywaniu tego, co z perspektywy organizmu jest najbardziej przydatne (Klawiter 2006: 8). Podejście to opiera się na dwóch założeniach. Po pierwsze, infor macja jest już gotowa, zadaniem organizmu jest odnalezienie jej w otoczeniu, nie ma więc potrzeby, aby postrzegający ją przetwarzał. Po drugie, in for ma cja ma postać ofert (affordances), które są rozsyłane przez przedmioty (Klawiter 2006: 8). Termin „afordancja” pochodzi od angielskiego czasownika to afford mieć środki na coś; mieć coś; pozwolić sobie na coś; sprawić komuś coś (Gibson 1979: 127). Według Gibsona (1977) afordancją czegoś nazywamy specyficzną kombinację własności substancji i powierzchni tego czegoś w odniesieniu do zwierzęcia. Tak rozumiane afordancje wykraczają poza dychotomię subiektywne-obiektywne. Amerykański psycholog zakłada bowiem komplementarność organizmu i środowiska. Do istoty oferty należy to, że "zwraca się" ona do uczestnika, a zatem wykracza poza obiektywny, czyli bezpodmiotowy opis fizycznych własności przedmiotu (Klawiter 2006: 9). Jednocześnie to, co z oferty zostanie wykorzystane przez organizm, zależy od fizycznej organizacji jego ciała (np. konstrukcji ciała, umiejscowienia organów zmysłowych i zdolności motorycznych) oraz od aktywności, w jaką jest on zaangażowany (Pokropski 2013: 47). W tym względzie istnieje duże podobieństwo pomiędzy tym, co o ofertach pisał Gibson, a poglądami Edmunda Husserla (1974: 27) czy Martina Heideggera (2004: 90-91).

Zdaniem Ingolda, z prezentowanego tu punktu widzenia, kluczowym elementem postrzegania jest $\mathrm{ruch} \mathrm{w}$ środowisku - postrzegający poznaje świat, poruszając się w nim. Koncepcja ta jest zbieżna z tym, co o percepcji pisał Merleau-Ponty (Migasiński 1995: 60); różnica pomiędzy rozważaniami francuskiego fenomenologa a myślą Gibsona polega na odmiennym sposobie rozumienia tego, co postrzegający spotyka na swojej drodze. Jak już zostało to opisane w pierwszej części artykułu (Wala 2016), dla amerykańskiego psychologa świat wysyła oferty, lecz jednocześnie jest on statyczny, zbudowany z zakrzepłych obiektów - w tym sensie jest „pozbawiony czucia” (Ingold, Keck 2013). Dystansując się od tego przekonania, Ingold powołuje się na autora Fenomenologii percepcji, według którego środowisko organizmu nie jest bierne, a postrzeganie nie byłoby możliwe w świecie, który sam nie odczuwa. Dla Merleau-Ponty'ego świat 
jest postrzegany, jakby był w ciągłym ruchu, a nasza percepcja jest elementem autopercepcji zamieszkiwanego świata. Różnica pomiędzy tymi perspektywami ma jeszcze jeden istotny wymiar. Ingold (2011: 128-129) wyjaśnia to, relacjonując rozmowę między filozofem i psychologiem, do której nigdy nie doszło, ale której przebieg można sobie wyobrazić na podstawie prac obu autorów: „Wyobraźmy sobie, że spotkali się w słoneczny, letni dzień. Siedzą sobie na trawie i patrzą w niebo. «Co widzisz?», pyta Merleau-Ponty'ego Gibson, na co ten odpowiada z rozmarzeniem: «jestem samym niebem, (...) moja świadomość jest nasycona bezkresnym błękitem». Gibson pozostaje niewzruszony i tylko zastanawia się: «Dlaczego ten Francuz nie odpowiedział na moje pytanie? Zapytałem przecież o to, co widzi, a nie o to, czym jest. Poza tym, jak on może mówić, że jest niebem, skoro siedzi tuż obok mnie na trawie?». W końcu jednak psycholog zabiera głos: «Wydaje mi się, że widzę niebo, nie światło (luminosity)». Merleau-Ponty mógłby odpowiedzieć Gibsonowi, że niebo nie jest niczym innym, niż światem światła, na który otwieramy się w widzeniu. «Gdy kontempluję błękit nieba, nie jestem postawiony wobec niego». Widzieć niebo to być niebem, odkąd jest ono światłem, postrzeganie wizualne nieba jest doświadczeniem światła”. Jak pisze dalej Ingold (2011: 129-130), wynika stąd, że: „widzenie, słyszenie i dotykanie rzeczy oparte jest na doświadczeniu światła, dźwięku i czucia. Jeśli Gibson wymusza na nas uczestnictwo w [doświadczeniu] powierzchni rzeczy, to Merleau-Ponty, przeciwnie, kieruje naszą uwagę na medium, w którym rzeczy są kształtowane i w którym mogą się rozpłynąć. Zamiast myśleć o nas samych jako o obserwatorach, przemieszczających się wokół obiektów znajdujących się na powierzchni uformowanego świata, winniśmy postrzegać siebie jako uczestników, zanurzonych całym swym jestestwem w nurcie świata-w-procesie, w świecie-poprzez-pogodę: widzimy w promieniach słońca, słyszymy w deszczu, czujemy w wietrze. Uczestnictwo nie jest czymś przeciwnym wobec obserwacji, jest raczej jej warunkiem, tak jak światło jest warunkiem widzenia rzeczy, dźwięk - słyszenia, czucie - dotykania ich. (...) Doświadczenie światła, dźwięku i czucia zalewa naszą świadomość. Dlatego tak ważna dla rozważania percepcji okazuje się pogoda. Nie jest ona tak bardzo przedmiotem naszego postrzegania, jak tym, w czym postrzegamy; warunkuje naszą zdolność widzenia, słyszenia, dotykania. Wraz z tym, jak zmienia się pogoda, zmianie ulegają także warunki, w których postrzegamy. Nie postrzegamy za każdym razem innych rzeczy, lecz te same rzeczy w inny sposób".

Umiejętne poruszanie się w środowisku, w którym działają inne organizmy, materiały pozostają w nieustannym ruchu (życie rzeczy), a pogoda wciąż ulega zmianie, wymaga "sensorycznej uwagi” (sensory awareness), rozumianej jako zdolność różnicowania, rozpoznawania, sytuowania i wydobywania sensu dźwięków, zapachów, smaków, barw, temperatury, faktur itp. Zdolność ta rozwija się wraz z rozwojem organizmu w środowisku.

Ingold wskazuje na wiązanie się tych porządków w procesie uczenia się. Sięga do źródłosłowu i znaczenia wyrazu edukacja wywodzącego się od łacińskiego słowa $\bar{e} d \bar{u} c \bar{o}$ - wychowywać, którego trzonem jest słowo dūcō - ciągnąć, prowadzić, 
kierować, obliczać (Ingold 2013b: 4). Wskazuje na dwa możliwe sposoby jego użycia, biegnące w przeciwstawnych kierunkach - do środka „in” i na zewnątrz „e,", „ex”. W pierwszym przypadku (indūcō - powlekać, wprowadzać) „skuteczność edukacji polega (...) na międzypokoleniowym przekazie pewnego już istniejącego porządku. Zgodnie z normatywnym kanonem zachodniej pedagogiki jest to dostarczanie treści kulturowych młodym umysłom, które natura uczyniła do tego zdolnymi" (Ingold 2014: 6). W drugim przypadku (edūcō - wyciągać, wyprowadzać) „edukacja to raczej wy-prowadzanie nowicjusza w świat” (Ingold 2014: 6).

Według Ingolda (2009: 125) w rzeczywistości edukacja nie polega tylko na przyswajaniu reprezentacji, lecz przede wszystkim na uczestnictwie w świecie, w żywym doświadczeniu. Jako taka edukacja jest ściśle powiązana z percepcją: „Uczymy się postrzegać poprzez nastrajanie lub uwrażliwianie całego systemu percepcyjnego na określone cechy naszego otoczenia. W procesie tym człowiek wyłania się nie jako istota, której wykształcone zdolności są wypełnione strukturami będącymi reprezentacjami świata, lecz jako centrum świadomości i sprawstwa, którego procesy rezonują z procesami toczącymi się w środowisku. $W$ tym kontekście wiedza rozwija się w obszarze praktyki wyznaczonym przez jego lub jej obecność jako bycie-w-świecie".

Proces transmisji wiedzy między pokoleniami polega więc przede wszystkim na pokazywaniu rzeczy i zjawisk nowicjuszowi (Ingold 2000: 21). Według Ingolda (2009: 124) „Uczenie się jest rezultatem instruowanego ponownego odkrywania informacji. W każdym kolejnym pokoleniu nowicjusze uczą się dzięki sytuacjom, w których stają oni przed pewnymi zadaniami, a ktoś pokazuje im, co robić i na co zważać, gdy działają pod kierunkiem bardziej doświadczonych dłoni. Pokazać komuś coś, to sprawić, by to coś dla tej drugiej osoby zaistniało, aby on lub ona mogli pojąć to wprost, czy to patrząc na to, czy też słuchając bądź dotykając tego. Postawiony w takiej sytuacji nowicjusz zostaje poinstruowany, by zwrócił uwagę na ten bądź inny aspekt tego, co można zobaczyć, dotknąć lub usłyszeć, tak aby umożliwić jemu lub jej «poczucie» tego".

Niewprawny jeszcze praktyk stopniowo nabiera wyczucia (Gibson 1979: 254). Powtarzając te same czynności w różnych okolicznościach, staje się biegły nie tyle w odtwarzaniu trajektorii ruchu, co nade wszystko w skutecznym i zręcznym wychwytywaniu pojawiających się znaczeń, afordancji, a w konsekwencji w efektywnym wykonywaniu zadania (Ingold 2000: 168). Dzięki temu z czasem potrafi „poruszać się w sposób, który jest nieustająco i subtelnie responsywny wobec niuansów własnych realizacji z odpowiednimi aspektami środowiska" (Ingold 2009: 128-129). Stopniowo uczy się, jak reagować na zmiany pogody, aktywność innych ludzi i organizmów, procesy, którym podlegają rzeczy. Wie, w jaki sposób rozróżniać zapachy, dźwięki, smaki, barwy, faktury istotnych elementów otoczenia, biorących udział w praktykach. Dowiaduje się, jak szybko i skutecznie odpowiadać na najdrobniejsze ich zmiany. Jego wiedza opiera się zatem na zdolności sytuowania informacji, nie zaś reprezentowania ich w umyśle. W tym sensie znaczenie nie jest dodane do strumienia surowych 
danych sensorycznych - jest raczej nieustannie generowane w ramach praktycznego zaangażowania człowieka w otaczający go świat (Ingold 2009: 128-129). W zależności od rodzaju aktywności, w jaką jesteśmy zaangażowani, będziemy mniej lub bardziej skłonni do wychwytywania poszczególnych znaczeń i ofert wysyłanych przez otoczenie. Zdolność ta rozwija się indywidualnie i stopniowo w ciągu życia, w ramach praktycznego zaangażowania organizmu w działanie. Edukacja uwagi staje się elementem rozwoju całego organizmu; nie można jej rozpatrywać bez uwzględnienia historii organizmu, realizacji konkretnych praktyk, w jakie się angażuje, procesu stawania się środowiska, rozwoju innych organizmów i życia rzeczy ${ }^{5}$.

Nawiązując do wcześniejszych fragmentów artykułu, szczególnie propozycji Howesa, warto wskazać, że rozważania akcentujące znaczenie doświadczenia w procesie uczenia się świata nie negują roli, jaką ogrywa w nim język. Ingoldowi (2000: 21) zależy raczej na podkreśleniu tego, że język i symbole nie są kluczowymi elementami edukacji percepcji, zaś wiedza sensoryczna nie oznacza akumulacji informacji, lecz wyraża się w zdolności ich sytuowania, rozumienia znaczenia w kontekście bezpośredniego zaangażowania percepcyjnego w środowisku działania. Według Ingolda przedstawiciele różnych kultur w pewnym sensie rzeczywiście żyją w różnych światach sensorycznych, wynika to jednak z faktu wypracowywania odmiennych praktyk, zamieszkiwania różnych środowisk a zatem rozwijania się w odmiennych kontekstach ${ }^{6}$. Zdolność wychwytywania wybranych bodźców i przy pisywania im określonych znaczeń wymaga zatem od nowicjusza nie tyle przyswojenia danego systemu znaczeń, co przede wszystkim nabycia umiejętności, dla której bodźce te mają swój sens.

\section{Produkcja, historia, zamieszkiwanie i linie}

W niniejszej części spróbuję poukładać wszystkie elementy świata opisanego przez Ingolda. W pierwszej części artykułu (Wala 2016) przedstawiłam środowisko zamieszkiwania. Za Gibsonem, antropolog wskazuje na trzy podstawowe jego składniki: powierzchnie, substancje i medium. Powołując się na Merleau-Ponty'ego,

\footnotetext{
${ }^{5}$ Poszczególni autorzy używają różnych określeń mających oddać istotę tego procesu: Gibson pisze o edukacji uwagi, David F. Sutton o edukacji pamięci, Jackson o edukacji percepcji, a PhillipVannini i Denis Waskul o somatycznym rozwoju. Wszyscy oni starają się jednak zwrócić uwagę na procesualny i praktyczny charakter nabywania kompetencji percepcyjnych. (Zob.: Jackson 1983: 329; Sutton 2006: 92; Vannini, Waskul, Gottschalk 2012).

${ }_{6}^{6}$ Por.: „Weźmy dwoje ludzi pochodzących z odmiennych środowisk i umieśćmy ich w tej samej sytuacji: będą się różnili sposobem jej oceny. Dlaczego? (...) Nasze postaci spostrzegają swoje otoczenie $\mathrm{w}$ alternatywny sposób, ponieważ zostały nauczone, dzięki wcześniejszym doświadczeniom $w$ realizowaniu rozmaitych zadań praktycznych wymagających określonych ruchów ciała oraz wrażliwości, orientowania się w otoczeniu i zajmowaniu się jego cechami w rozmaity sposób. Różnica ta, innymi słowy, nie leży w sposobach reprezentowania środowiska wewnątrz ich głów, lecz w tym, jak odkrywają oni to, co daje ono ich aktywnościom" (Ingold 2009: 19).
} 
twierdzi on, że pomiędzy dwoma ostatnimi zachodzi nieustanna wymiana, fluktuacja, ruch. To one są warunkiem życia. Ich wyrazem jest pogoda, dlatego antropolog często pisze o środowisku, że jest to „świat-poprzez-pogodę".

Dalej szkocki antropolog wyjaśnia, że tym, co znajduje się w środowisku, są rzeczy i organizmy. Podlegają one tej same zasadzie, która obejmuje całe środowisko, tj. wymianie pomiędzy medium i substancjami. Dzięki niej rzeczy żyją, tzn., zmieniają się w fluktuacji medium, mogą więc działać, wpływać na organizmy i inne rzeczy. Antropolog przypisuje rzeczom zdolność wysyłania informacji do środowiska i działających w nim organizmów w formie afordancji, które mogą się zmieniać w zależności od odbiorcy i podejmowanej przez niego czynności. Konstatacja ta nie prowadzi jednak do wniosku, że rzeczy i organizmy są tym samym - przeciwnie, występuje między nimi zasadnicza różnica.

Zdaniem Ingolda organizmy należy traktować niczym systemy rozwojowe, które, podejmując różnego typu działania w swoim otoczeniu, przekształcają się w trakcie życia. Rozwój organizmu jest zawsze rozpatrywany w kontekście relacyjnym, w którym stawanie się organizmu jest częścią procesu stawiania się świata. Antropolog podkreśla podobieństwo żywych organizmów różnego typu, nie czyni on wyraźnej dystynkcji pomiędzy ludźmi i innymi organizmami. Zdaniem Ingolda istoty żywe cechuje zdolność postrzegania, która wraz z całym organizmem rozwija się w kontekście środowiska i realizowanych przez siebie zadań. Percepcja polega na zdolności wychwytywania i sytuowania afordancji wysyłanych przez rzeczy, inne organizmy, czyli środowisko. Dzięki zdolności postrzegania organizmy są w stanie poruszać się w nieustająco zmieniającym się i fluktuującym środowisku, wśród innych poruszających się i działających organizmów oraz rzeczy. Tym zatem, co wyłania się z propozycji antropologa, jest życie, ruch, rozwój, wzrost i współzależność (Ingold 2014).

Ingold nigdy nie opisał swojej teorii w taki sposób, jak została ona przedstawiona zarówno w niniejszym artykule, jak i w jego pierwszej części (Wala 2016). Choć zdarzało się, że antropolog pisał osobno o środowisku, rzeczach, organizmach i percepcji, to jednak częściej łączył wszystkie te wątki. Wobec tego zaprezentowany podział należy potraktować jako moją autorską próbę uporania się z wielością i bogactwem, jakie można znaleźć w jego pracach. Sam Ingold (2011: 4) wskazuje na inny sposób porządkowania teorii, jak pisze: „patrząc na wysiłek, jaki podjąłem, aby przywrócić antropologię życiu, mogę wskazać cztery fazy, z których każda obracała się wokół wybranego słowa-klucza". Aby zrozumieć, co dokładnie antropolog ma na myśli, spróbujmy jeszcze przez chwilę przyjrzeć się jego teorii i tym razem poukładać podejmowane przeze mnie wątki w odniesieniu do ingoldowskich słów-kluczy: produkcji, historii, zamieszkiwania i linii.

Zasadniczym motywem rozwijającej się od lat teorii Ingolda jest chęć przezwyciężenia hylemorfizmu oraz tego, co nazywa on logiką inwersji (logic of inversion), opierającą się na przekonaniu, że życie toczy się w jasno zakreślonych granicach - linie na mapie, ściany mieszkania, powierzchnie przedmiotów, skóra ciała. Według logiki inwersji świat składa się z zamkniętych całości, które 
przemieszczają się i/lub zajmują jego powierzchnię. Ten sposób myślenia można przedstawić przy pomocy okręgu zakreślonego na kartce papieru.

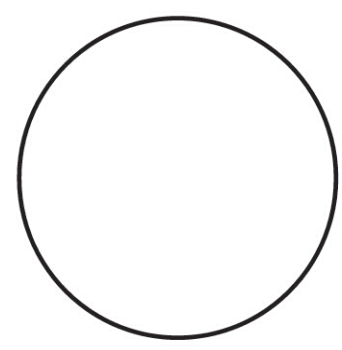

Rys. 1. Logika inwersji

Według Ingolda można wydzielić trzy zasadnicze elementy tej figury: "w środku”, "na zew nątrz" i wytyczoną między nimi "granicę". Organizm lub przedmiot rozumiany przez pryzmat logiki inwersji jest całością otoczoną przez środowisko, z którym - zgodnie ze swą naturą - wchodzi w relacje. Jak twierdzi antropolog, organizm jest "tu”, środowisko "tam”, życie zaś stanowi integralną własność organizmów, które zajmują świat. Wystarczy jednak nieco inaczej spojrzeć na tę figurę, aby odkryć jej zupełnie nowe znaczenie (zob. rys. 2.).

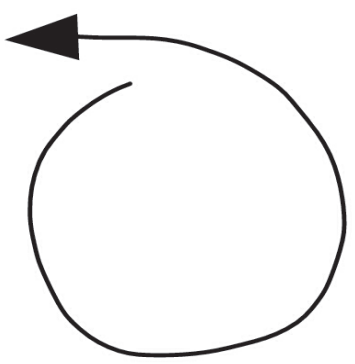

Rys. 2. Odwrócenie inwersji

Dzięki zmianie perspektywy okazuje się, że okrąg jest zapisem ruchu, gestu, który nakreślił figurę na kartce. Koncentrując się na tym ruchu, odkrywamy brak elementów, z których składał się pierwszy rysunek, czyli „w środku”, „na zewnątrz" i wytyczonej "granicy". Mamy za to ścieżkę ruchu czy raczej wzrostu, rozwoju, życia (Ingold 2006: 13). Ruch ten jest emanacją "ontologii, która $\mathrm{w}$ swym centrum stawia proces formowania, nie zaś jego finalny produkt, przepływ materii, nie zaś zastygłą magmę materii" (Wala 2016: 204). Ów ruch jest przedmiotem zainteresowań Ingolda, który próbuje na różne sposoby opisać go w swoich pracach.

Pojęcie produkcji wyrasta z refleksji nad ruchem ludzi i zwierząt, który służy wytwarzaniu nowych rzeczy i stanów. Ingold rozważał, czym jest ten ruch i powołując się na wczesne prace Karola Marksa i Friedricha Engelsa - wskazuje, że w przypadku organizmu zanurzonego w środowisku życia proces produkcji 
nie jest ograniczony do wytwarzania obiektów. Nie zaczyna się od wyobrażenia i nie kończy na obiekcie, lecz trwa bez początku i końca - jest procesem, w którym formy te są nieustająco generowane. Wyrazem tego stanowiska jest sprzeciw, jaki pojawia się w głowie twórcy, wobec utożsamiania procesu produkcji z transformacją projektu na produkt końcowy. Choć antropolog zgadza się z tym, że ludzie wykazują unikalną w świecie istot żywych zdolność "przewidywania form, zanim zostaną one wdrożone w życie”, to uważa, że aktywność większości z nas podobnie jak innych organizmów - wyraża się, po pierwsze, $\mathrm{w}$ akcie produkcji polegającym na bricolage'u, pracy z materiałami, uczestnictwie w nieustannym powstawaniu formy (Ingold 2011a: 10); po drugie, w towarzyszeniu materiałom w procesie powstawania, nabrzmiewania, wzrostu, rozwoju, piętrzenia, pękania, zapadania się; po trzecie, w tkaniu, w szczególnym, relacyjnym kontekście praktycznego zaangażowania w środowisko (Ingold 2011a: 6). Jak pisze antropolog, „ludzie nie sprowadzają pomysłów (idei), planów i mentalnych reprezentacji na świat, odkąd sam świat (...) jest domem ich myśli. Tylko dlatego, że już w nim działamy, mieszkamy, możemy myśleć myśli, które przychodzą nam do głowy" (Ingold 2011a: 6).

Pojęcie historii wyrasta z dalszego namysłu nad ruchem, wzrostem i rozwojem ludzi oraz innych istot żywych. Ingold stara się określić istotę podziału na organizmy żywe, które podlegają procesom ewolucji, i te, które mają swoją historię. Udowadnia, że podział ten jest niesłuszny - wszystkie istoty żywe podlegają podobnym procesom rozwoju. Poza tym wskazuje, że nie można wypreparować działań ludzi i innych organizmów ze środowiska i analizować ich w odosobnieniu, albowiem to właśnie związki z innymi organizmami i innymi komponentami środowiska warunkują ich ruch, wzrost, rozwój, życie. Wobec tego w yłą c zenie ludzi ze świata natury, tak jak i zwierząt oraz roślin z badanego świata, jest błędem, ponieważ, akcentując aktywność jednego tylko zbioru aktorów, pomija się wzajemną zależność ludzi i nie-ludzi oraz złożoność środowiska7. Zdaniem Ingolda (2002: 22) wszystkie organizmy i rzeczy wspólnie wyplatają tkankę środowiska - ich połączony ruch tworzy warunki dla egzystencji obecnych i przyszłych pokoleń: „z tego punktu widzenia, historia jest raczej procesem, za pomocą którego ludzie i ich środowisko nieustannie powstają, każde w odniesieniu do tego drugiego".

Pojęcie zamieszkiwania pozwala Ingoldowi znieść podział na ludzi i inne organizmy żywe. Antropolog rozumie zamieszkiwanie jako pierwotną kondycję wszystkich istot żywych - ludzi, zwierząt, roślin, innych komponentów

7 Por.: „Jeśli ludzie z jednej strony i zwierzęta oraz rośliny z drugiej mogą być postrzegane naprzemiennie jako komponenty swoich środowisk, to nie możemy już dłużej myśleć o tych pierwszych jako o istotach zamieszkujących własne światy społeczne, poza światem natury, w którym toczy się życie pozostałych istot żywych. Zarówno ludzie, jak i zwierzęta wraz z roślinami, od których zależy ich życie, wspólnie uczestniczą w tym samym świecie. Formy, jakie przybierają, nie są ani z góry określone, ani narzucone, lecz wyrastają w relacyjnym kontekście ich wielorakiego zaangażowania. Mówiąc wprost, istoty ludzkie w swoim codziennym życiu nie przekształcają świata, lecz wraz z istotami innego rodzaju odgrywają swoją rolę w jego samoprzekształcaniu" (Ingold 2002: 19). 
środowiska. Oznacza ono zdolność umiejętnego, uzmysłowionego i responsywnego działania zarówno ludzi, jak i innych organizmów w swoim otoczeniu. Zdolność ta jest rozwijana dzięki zdobywanym doświadczeniom. Tylko dlatego, że zamieszkujemy, potrafimy budować, tworzyć, wymyślać, a „formy, które tworzymy, niezależnie od tego, czy w wyobraźni czy na ziemi, wyrastają w nurcie aktywności, w które jesteśmy włączeni, w szczególnym relacyjnym kontekście praktycznego zaangażowania z otoczeniem" (Ingold 2011a: 10). Zamieszkiwanie zatem wyraża się $w$ codziennych praktykach, rutynowych działaniach, w wyobraźni, w ciągłym zaangażowaniu mieszkańców w świat. Nie jest ono ani obiektywne i niezmienne, ani też subiektywnie i jednostkowo zdeterminowane, lecz staje się dzięki aktywności wszystkich elementów składających się na środowisko życia.

W fazie linii antropolog koncentruje się na opisie relacji pomiędzy wieloma elementami wzrastającymi i współtworzącymi środowisko, i podlegającymi jego samostawaniu. Oczywiście wyobrażanie organizmu jako pojedynczej linii jest dużym uproszczeniem. Żywy organizm, zdaniem Ingolda (2007; 2011a), nie jest jedną linią, lecz całą ich wiązką; przypomina supeł, od którego odchodzą liczne odnogi. Takie porównanie może wydać się zwykłą metaforą, ale wystarczy spojrzeć na organizm pod mikroskopem, aby przekonać się, że nawet $\mathrm{w}$ sensie materiałowym ciało jest uplecione z linii. Przykładem niech będą tkanki, które - jak pisze Ingold (2008: 1806) - są uformowane z mnóstwa ściśle ze sobą splecionych małych niteczek, tworzących tym samym wrażenie koherentnej powierzchni.

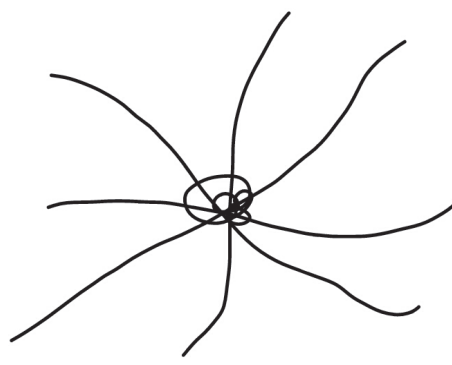

Rys. 3. Węzeł

Według Ingolda powinniśmy wyobrażać sobie organizm nie jako zwarty obiekt, ograniczoną skórą i błonami ciała subiektywność, która może wprawiać siebie $\mathrm{w}$ ruch i przenosić się z miejsca na miejsce. Organizm jest raczej ciągle rozgałęziającą się siecią linii wzrostu, jest kłączem, o którym pisali Gilles Deleuze i Felix Guattari (2015: 8-30). Zdaniem Ingolda (2008: 1807) przypomina on grzybnię. W pewnym stopniu obrazuje to rys. 4 . 


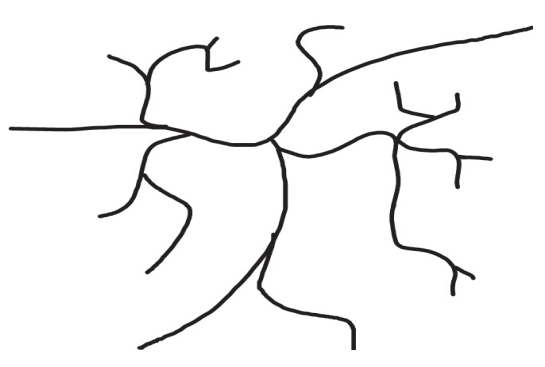

Rys. 4. Grzybnia

Jak twierdzi Ingold (2008: 1807), środowisko nie otacza organizmu, ponieważ nie można otoczyć sieci bez jednoczesnego zakreślenia wokół niej granicy, to zaś oznaczałoby powrót do myślenia według logiki inwersji. Zamiast tego powinniśmy wyobrazić sobie, że linie wyrastające z różnych źródeł wiążą się i przeplatają z liniami organizmu. Każda taka linia wchodzi zatem w relacje, nie są to jednak relacje pomiędzy jedną rzeczą i drugą - pomiędzy organizmem „tu” i środowiskiem „tam”. Proces, w którym organizmy i otaczające je materiały wspólnie uczestniczą w wyplataniu nowych rzeczy czy miejsc, polega na czułym i uważnym korespondowaniu (correspondence) pomiędzy nimi. Korespondowanie jest ruchem w czasie rzeczywistym, jest też ściśle związane z percepcją i czuciem (Ingold 2013a: 105).

Środowisko jest domeną splątania (domain of entanglement), a wspólnie z organizmami, roślinami i rzeczami tworzy „teksturę zamieszkiwanego świata”. Pisząc o teksturze, Ingold (2013a: 105) ma na myśli „organizm konstytuujący się w polu relacji”. Pole składa się nie z połączonych punktów, ale ze splątanych linii, nie jest siecią (netowork), lecz tka niną (meshwork).

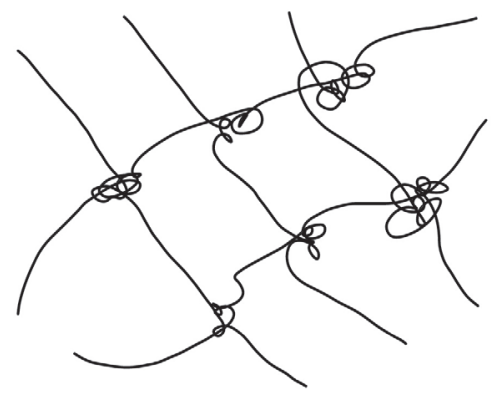

Rys. 5. Tkanina

Tkanina nie jest zawieszona w próżni, lecz jest zanurzona w przepływach medium, atmosfery, w świecie-poprzez-pogodę. Nie jest też statyczna, ponieważ każda z linii jest zapisem ruchu. W końcu, nie jest przestrzenną konstrukcją, ponieważ nie jest opisem relacji pomiędzy różnymi punktami - tkanina jest tkana ruchem, wzrostem organizmów i rzeczy. Proces, w którym organizmy i otaczające je materiały wspólnie uczestniczą w wyplataniu tkaniny, Ingold (2015: 154) 
nazywa czułym i uważnym korespondowaniem linii - correspondence of lines. Korespondowanie jest ruchem, „w którym jedna rzecz nieustannie odpowiada drugiej, podobnie jak dzieje się to w konwersacji" (Ingold, Wala, Zych 2014: 12). Tkanina jest więc temporalnym związkiem splątanych linii życia ${ }^{8}$. To rzeczywistość w trakcie stawania się (Ingold, Wala, Zych 2014: 13).

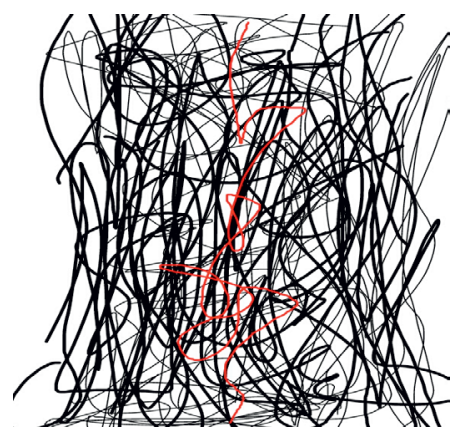

Rys. 6. Rozwój uzmysłowionego organizmu w środowisku

Podsumowując, w trakcie swojego życia produkujemy, tworzymy historię, zamieszkujemy, tkamy. Nasze zamieszkiwanie polega na (współ)tworzeniu historii, w której produkujemy i konsumujemy - wyplatając, wplątując się w związki, wiążąc i rozwiązując, korespondując, uczestniczymy w stawianiu się świata. Oto klucz do antropologi iżcia Tima Ingolda.

\section{Literatura}

Angutek, D. (2010). Kanadyjska antropologia zmysłów - alternatywa wobec postmodernizmu. $L u d, 94,221-242$.

Classen, C. (1997). Foundations for an anthropology of the senses. International Social Science Journal, 49(153), 401-412.

Classen, C. (2012). The Deepest Sense: A Cultural History of Touch. Studies in Sensory History. Urbana-Chicago: University of Illinois Press.

\footnotetext{
${ }_{8}$ Pisząc o tkaninie (meshwork), Ingold stara się uchwycić kształtowanie się świata-poprzez-pogodę. Figura tkaniny służy w jego koncepcji wyrażeniu ruchu, procesu (współ)stawania się organizmów - ludzi, zwierząt, grzybów, bakterii, roślin, rzeczy oraz pogody. Jest ona z jednej strony pewną konstrukcją myślową, która zmienia nasze wyobrażenie o świecie, z drugiej strony jest także realnym bytem - już nasze ciała i ciała innych istot żywych przypominają swą strukturą ingoldowiski meshwork - odwzorowuje związki, korespondencję pomiędzy poszczególnymi elementami działającymi w świecie. Warto dodać, że linia nie jest tylko figurą ontologii Ingoldowskiej, która opisuje istotę życia, ale także czymś, co jest historycznie zmienne. W książce Lines Ingold (2015) pisze także o historyczności konceptualizowania i tworzenia linii od rysunków, po pismo i druk. W innym miejscu zaznacza: „twierdzę, że rysunek nie jest obrazem (image), reprezentacją czegokolwiek, jest raczej linią dojrzewającej myśli, jej rozwoju. Gdy myślimy o czymś, robimy to też naszymi rękoma, pozostawiając ślad wraz z sekwencją gestu. (...) Ruch ręki i prowadzący ją ruch myśli korespondują z ruchem czegokolwiek, w czym uczestniczy w świecie osoba ryzująca i czemu odpowiada (Ingold, Wala, Zych 2014: 12).
} 
Csordas, T. (1990). Embodiment as a Paradigm for Anthropolog. Ethos, 18(1), 5-47.

Csordas, T. (1993). Somatic Modes of Attention. Cultural Anthropology, 8(2), 135-156.

Csordas, T. (1999). Embodiment and Cultural Phenomenology. W: G. Weiss, H.F. Haber (eds.), Perspectives on Embodiment. The Intersection of Nature and Culture (s. 143-163). New York-London: Routledge.

Deleuze, G., Giattari, F. (2015). Tysiąc Plateu. Przeł. J. Bednarek. Warszawa: Fundacja Bęc Zmiana.

Dmitrzak-Węglarz, M., Hause, J. (2009). Mechanizmy epigenetyczne w chorobach psychicznych i zaburzeniach funkcji poznawczych. Psychiatria, 6(2), 51-60.

Farnell, B. (1994). Ethno-Graphies and the Moving Body. Man, 29(4), 929-974.

Farnell, B. (1999). Moving Bodies, Acting Selves. Annual Review of Anthropology, 28, 341-373.

Farnell, B., Varela, Ch.R. (2008). The Second Somatic Revolution. Journal for the Theory of Social Behaviour, 38(8), 215-240.

Firth, Ch. (2011). Od mózgu do umystu. Jak powstaje nasz wewnętrzny świat. Przeł. A. Binder. Warszawa: Wydawnictwo Uniwersytetu Warszawskiego.

Gibson, J. (1966). The senses considered as perceptual systems. Boston: Houghton Mifflin.

Gibson, J. (1977). The Theory of Affordances. W: R. Schaw, J. Bransford (eds.), Perceiving, Acting and Knowing (s. 127-143). New York: Harcourt Brace Jovanovich.

Gibson, J. (1979). The Ecological Approach to Visual Perception. Boston: Houghton Mifflin.

Heidegger, M. (2004). Bycie i czas. Przeł. B. Baran. Warszawa: Wydawnictwo Naukowe PWN.

Herzfeld, M. (2004). Antropologia. Praktykowanie teorii w kulturze i społeczeństwie. Przeł. M.M. Piechaczek. Kraków: Wydawnictwo Uniwersytetu Jagiellońskiego.

Howes, D. (2003). Sensual Relations. Engaging the Senses in Cultural and Social Theory. Michigan: The University of Michigan Press.

Howes, D. (2005). Introduction: Empires of the Senses. W: D. Howes (ed.), Empire of the Senses. The Sensual Culture Reader (s. 1-17). Oxford-New York: Berg.

Howes, D., Classen, C. (1991). Sounding Sensory Profiles. W: D. Howes (ed.), The Variaties of Sensory Experience: A Sourcebook in the Anthropology of the Senses (s. 257-288). TorontoBuffalo-London: University of Toronto Press.

Howes, D., Classen, C. (2014). Ways of Sensing. Understanding the Senses in Society. London-New York: Routledge.

Husserl, E. (1974). Idee czystej fenomenologii i fenomenologicznej filozofii. Księga druga. Przeł. D. Gierulanka. Warszawa: Państwowe Wydawnictwo Naukowe.

Ingold, T. (2007). Lines. A Brief History. London-New York: Roudledge.

Ingold, T. (1991). Becoming Person: Consciousness and Sociality in Human Evolution. Cultural Dynamics, 4, 355-378.

Ingold, T. (2000). The Perception of the environment: esseys on livelihood, dwelling and skill. London-New York: Routledge.

Ingold, T. (2002). On the Distinction between Evolution and History. Social Evolution $\mathcal{E}$ History, 1(1), 5-24.

Ingold, T. (2004). Beyond Biology and Culture. The meaning of evolution in relational world. Social Anthropology, 12(2), 209-221.

Ingold, T. (2005). Kultura i postrzeganie środowiska. Przeł. G. Pożarlik. W: M. Kempny, E. Nowicka (red.), Badanie kultury. Elementy teorii kultury (s. 73-86). Warszawa: Wydawnictwo Naukowe PWN.

Ingold, T. (2006). Rethinking Animate, Re-Animate Thought. Ethnos, 71(1), 9-20.

Ingold, T. (2008). Binding against boundaries: entanglement of life in an open world. Enviroment and Planning, 40, 1796-1810. 
Ingold, T. (2009). Ewoluujące umiejętności. Przeł. M. Polaszewska-Nicke. W: A. Klawiter (red.), Formy aktywności umystu. Ujęcie kognitywistyczne. Ewolucja i złożone struktury poznawcze. T. 2 (s. 110-131). Warszawa: Wydawnictwo Naukowe PWN.

Ingold, T. (2011a). Being Alieve. Esseys on Movement, Knowledge and Description. LondonNewYork: Routledge.

Ingold, T. (2011b). Worlds of sense and sensing the world: a response to Sarah Pink and David Howes. Social Anthropology/Anthropologie Sociale, 19(3), 313-317.

Ingold, T. (2011c). Repley to David Howes. Social Anthropology/Anthropologie Sociale, 19(3), s. 323-327

Ingold, T. (2013a). Making: Anthropology, Archeology, Art and Architecture. London-New York: Routledge.

Ingold, T. (2013b). The maze and the labyrinth: walking and the education of attention, www. issuu.com/stereographic/docs/walkon_for_issuu [dostęp: 14.03.2013].

Ingold, T. (2014). Człowiek to czasownik. Autoportret. Pismo o Dobrej Przestrzeni, 2(45), 4-9. Ingold, T. (2015). The Life od Lines. London-New York: Routledge.

Ingold, T. Keck F. (2013). Debate: Anthropology comes to life, www.vimeo.com/54253745 [dostęp: 20.04.2013].

Ingold, T., Wala, K., Zych, M. (2014). Ruch, którym jesteśmy, zawiera też ruch naszych myśli. Z Timem Ingoldem rozmawiają Katarzyna Wala i Magdalena Zych. Autoportret. Pismo o Dobrej Przestrzeni, 2(45), 10-15.

Jackson, M. (1983). Knowledge of the body. Man, 18(2), 327-345.

Jakubowska, H. (2009). Socjologia ciała. Poznań: Wydawnictwo Naukowe UAM.

Jakubowska, H. (2012). Ciało jako przedmiot badań socjologicznych - dylematy, pominięcia, możliwości. Przegląd Socjologii Jakościowej, 7(2), 12-31.

Jewdokimow, M., Łuksiuk, M. (2009). Miejsce i ciało w kontekście podróży, www.depot.ceon. $\mathrm{pl} /$ bitstream/handle/123456789/307/cialo\%20i\%20miejsce\%20w\%20kontekscie $\% 20$ podrozowania\%20(3,pdf?sequence=1 [dostęp: 23.05.2013].

Kaliski, P. (2008). Koncepcja spostrzegania bezpośredniego J.J. Gibsona na podstawie pozycji "The eclogicalapproach to visualperception", www.kalski.jezuici.pl/doc/mgr_rk.pdf [dostęp: 3.02.2013].

Klawiter, A. (2006). Jak rozpoznajemy narzędzia. Hipoteza filozoficzno-kognitywistyczna, www. staff.amu.edu.pl/ klawiter/narzedzia.pdf [dostęp: 4.05.2013].

Łastowski, K. (2009). Wprowadzenie. O dwóch ujęciach epigenezy człowieka: interakcyjnym i procesualnym. W: A. Klawiter (red.), Formy aktywności umystu. Ujęcie kognitywne. Ewolucja i złożone struktury poznawcze. T. 2 (s. 9-16). Warszawa: Wydawnictwo Naukowe PWN.

Merleau-Ponty, M. (2001). Fenomenologia percepcji. Przeł. M. Kowalska, J. Migasiński. Warszawa: Aletheia.

Messay, D. (2007). For Space. Los Angeles-London-New Delhi: SAGE.

Migasiński, J. (1995). Merleau-Ponty. Warszawa: Wiedza Powszechna.

Pokropski, M. (2013). Cielesna geneza czasu i przestrzeni. Warszawa: Wydawnictwo IFiS PAN.

Sutton, D.F. (2006). Cooking Skill, the Senses, and Memory: the Fate of Practical Knowledge. W: E. Edwards, Ph-Ch. Gosden (eds.), Sensible Object: Colonialism, Museum and Material Culture. Oxford-New York: Berg.

Vannini, P., Waskul, D., Gottschalk, S. (2012). The Senses in Self, Society, and Culture. A Sociology of the Senses. New York-London: Routledge.

Wala, K. (2016). Ułożyć świat na nowo. Rekonstrukcja koncepcji Tima Ingolda (cz. I). Etnografia. Praktyki, Teorie, Doświadczenia, 2, 189-209. 


\section{SUMMARY}

Arranging the world anew. Re-creation of Tim Ingold's concept/idea (part II)

The aim of this paper is a reconstruction of Tim Ingold's theoretical proposal. The present text is the second of a three-part study that will be published in subsequent volumes of "Ethnography". This section presents Ingold's considerations regarding the organism and perception. Author try to merge all the elements (environment, things, organism and perception) in order and present Ingold's theory. In the following article Author will close the series of articles with a conclusion regarding the possible use of Ingold's theory in ethnographic research, including sensory ethnography.

Keywords: Tim Ingold, organism, perception, environment, education, meshwork, correspondence. 